\title{
EFFECT OF SOME SELECTED FUNGICIDES ON THE GROWTH OF TISSUES CULTURED IN VITRO
}

\author{
W T P S K Senarath \\ Department of Botany, University of Sri Jayewardenepura \\ Nugegoda.
}

Fungi were isolated from contaminated tissue cultures. They were initially characterised according to the colour and the texture of the colony and an identification number was given to each. Pathogens were inoculated into seven different media in order to detcrmine the suitable medium for the rapid growth of the fungi and to obtain pure cultures. They were incubated at $27 \pm l^{\prime \prime} \mathrm{C}$.

Five different fungicides (diathanc, systhane, rovral, tumble blight and thiophenatemethyyl) were prepared at $100 \mathrm{ppm}$ concentration. Sterile filter paper circles $(5 \mathrm{~mm})$ were wetted with $10 \mathrm{l}$ of each and were placed separately on the agar plates inoculated with fungal spores. They were in duplicates and were incubated for seven days. Using the diameter of the growth free area around the filter paper circles, the resistance or the susceptibility of the fungi to each fungicide was determined.

Most of the fungi were susceptible to dithane and thiophenate-methyl, thus these two were chosen for determination of the growth interference of fungicides on tissue cultures. These two fungicides were added to the tissue culture media alter autoclaving the medium at 0 (control), $20 \mathrm{ppm}$ and $1000 \mathrm{ppm}$ concentrations. Twenty-five replicates per treatment were used. After six weeks of incubation, the total number of newly produced juvenile leaves, percentage of fungal contamination and the percentage number of surviving explants were observed. There was a significant difference between the two fungicides used and also between the concentrations used. The interference of the fungicide to the growth of the tissue was minimal when thiophenate-methyl was added at $10 \mathrm{ppm}$ concentration. Higher concentrations retard the plant growih significantly. 